ELORE (ISSN 1456-3010), vol. 20 - 1/2013.

Julkaisija: Suomen Kansantietouden Tutkijain Seura ry.

[http://www.elore.fi/arkisto/1_13/haapoja2.pdf]

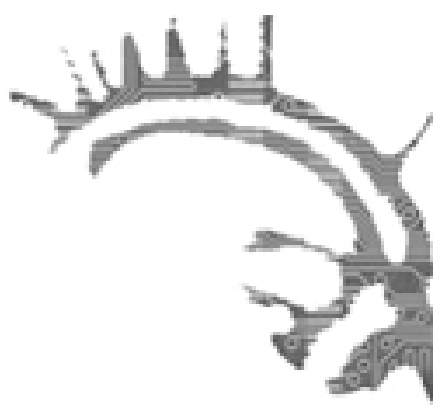

\title{
KirJA-ARVIO
}

\section{PYSY SUOMESSA PYHÄNÄ}

JALKANEN, PEKKA, LAITINEN, HEIKKI, TENHUNEN, ANNA-LIISA 2010: Kantele. Helsinki: SKS. 511 sivua.

\section{Heidi Haapoja}

Kantele-tietokirja julkaistiin muutamia vuosia sitten Kanteleliiton aloitteesta vastaamaan puutteeseen, joka on kieltämättä kyseisen instrumentin maineen huomioon ottaen melko hämmentävä: soittimesta ei ole aiemmin julkaistu mittavia tutkimuksia. Erilaisia soitto- ja rakennusoppaita toki on ollut jo pitkään, samoin lyhyempiä yleisesityksiä, mutta Kanteleen tapaista ei ole ennen nähty. 500-sivuinen Kantele tavoittelee populaarin tietokirjan luonnetta ja pääsyä jokaisen kirjahyllyyn, mutta samalla sen lukeminen vaatii monin kohdin erityisosaamista. Kirja onkin jännittävä tutkimuksen, hienoisen paatoksen, innostuksen ja harvinaisen kuvamateriaalin hybridi.

Kirjan kirjoittajiksi on valikoitunut rutinoitunut asiantuntijajoukko: kansanmusiikin emeritusprofessori Heikki Laitinen, folkloristi-itkuvirsitutkija Anna-Liisa Tenhunen ja säveltäjä Pekka Jalkanen. Jokaiselle kirjoittajalle on oma syventymiskohteensa. Laitinen ruotii kanteleen historiaa, Tenhunen sen symboliasemaa ja nykyisiä näkymiä. Jalkanen lähestyy aihetta musiikkianalyyttisesta näkökulmasta ja tarjoaa tulkintaperspektiivejä kantelemusiikkiin.

\section{KAIKEN TAKANA ON VÄINÄMÖINEN}

Heikki Laitisen osiossa hämmästyttää laaja perehtyneisyys 1700- ja 1800-lukujen kansanmusiikkiteksteihin ja ajan ilmapiiriin. Myös pienistä detaljeista rakennettu ko- 
konaiskuva on vaikuttavaa luettavaa. Laitisen kantelehistoriikki keskittyy väistämättä - muunlaisten dokumenttien ja kuvausten puutteessa - tarkastelemaan aihetta vanhan tutkimuskirjallisuuden fragmenttien, taideteosten ja runoesimerkkien kautta. Tämäntapaisessa tyylittelyssä Laitinen on mestarillinen sanankäyttäjänä, mutta nykylukijalle joissakin kohdissa esiin astuva haaviomainen poeettisuus tai Matti Kuusen lainaaminen merkittävissä kohdissa - ei pelkästään tutkimushistoriallisissa konteksteissa - herättää kysymyksiä. Onko relevanttia nostaa esiin juuri näitä kaikkein kaunopuheisimpia kirjoituksia esimerkiksi kalevalamittaisen runouden tutkimuksen piiristä, kun olemassa on tuoreempiakin päätelmiä runojen myyttisistä maailmoista? Laitinen lainaa Kuusta muun muassa pohtiessaan Kanteleen synty -runojen taustaa ja valitsee esimerkeikseen melko latautuneita pätkiä:

Väinämöisen kanteleensoitto -runon tuntematonta sepittäjä on pidetty ja voidaan syystä pitää vuosituhantensa nerokkaimpana suomalaisena runoilijana. Hänen runoelmassaan on ennenkuulematonta eloa ja iloa ja havainnollisuutta, on vauhtia ja ääntelyä ja kuuntelua, ihmisten ja eläinten kirjavaa taustajoukkoa ja detaljien vaarinottoa. Varhaisimpien kausien runoudella oli ennen muuta rituaalisen juhla- ja opetusrunouden leima; myös runo Väinämöisen veneestä ja kanteleesta laulaa heeroksen kunniaa, mutta sen mukana saapuu pohjoiseen pakanamaahan ensi kerran runon kauneus kauneuden itsensä takia; esteettisen elämyksen raikas, tuore, pyyteetön täyteläisyys.

(s. 97; ks. Kuusi 1957, 114-115.)

Toisaalta, teoksen tietokirjamaisen luonteen huomioon ottaen, kuusimaiset kielikuvat ja poeettiset ilmaisut ovat helposti lähestyttäviä ja ymmärrettäviä. Ja kauniitahan ne toki ovat kaikessa mahtipontisuudessaan. Silti Laitisen osion parasta antia ovat yksityiskohtaiset aineistokuvaukset ja salapoliisimaiset lähteiden penkomiset. Laitinen on epäilemättä luodannut kaiken kanteleesta aikaisempina vuosisatoina kirjoitetun ja poiminut jokaisen pienenkin kanteleeseen viittaavan yksityiskohdan. Näistä fragmenteista on syntynyt tiheä kuvaus, jossa varmasti on paljon aiemmin tutkimatonta aluetta. Mielenkiintoisia ovat esimerkiksi Lönnrotin ja kanteleen suhteen kuvailu, samaten kanteleen roolin tarkastelu vanhoissa uskonnollisissa (lähinnä luterilaisissa) teksteissä. Viimeisimpänä mainittua tuskin on juuri kukaan aiemmin luodannut.

Kanteleen idiomaattisia eli soittimellisia ominaisuuksia tarkasteleva osio punoutuu Laitisen tekstissä yhteen soittajien ja historiallisten tapahtumien kuvailun kanssa. Tämä on hyvä ratkaisu, sillä instrumentti-idiomatiikka vaatii usein lukijalta jonkinasteista perehtyneisyyttä ja saattaa olla asiaan vihkiytymättömälle hiukan puuduttavaa luettavaa. Kauniit kuvat museosoittimista, soittotilanteista ja soittajista jaksottavat lukukokemusta. 


\section{SOIVA SYMBOLI}

Anna-Liisa Tenhusen osio on hiukan mahtipontisesti nimetty "Kanteleen suureksi nousuksi". Se käsittelee tekijöiden omin sanoin "kuihtumassa olleen kansallissoittimen elpymistä moderniksi ja monimuotoiseksi soittimeksi" (s. 168). Tenhusen aikakausi alkaa suurin piirtein 1900-luvun alusta, ja hänen aineistonsa on tästä syystä huomattavasti yksityiskohtaisempaa ja tarkempaa kuin Laitisen fragmentaarinen materiaali. 1900-luvun alusta alkaen kansanperinteen keruutyön, äänitallenteiden ja systemaattisen tutkimusotteen myötä kanteleeseen liittyvää aineistoa on paljon, itse asiassa todella paljon verrattuna moneen muuhun kansansoittimeen.

Tenhunen käsittelee tätä aineistoa asiantuntevasti, lähinnä soittajien näkökulmasta. Mielenkiintoisia osioita ovat esimerkiksi karelianistien järjestämien soitto- ja laulujuhlien kuvaukset sekä menettämisen ja katoavan perinteen huolen ilmapiirin esilletuonti. Vaikuttavia ovat myös ainakin allekirjoittaneelle ennennäkemättömät, 1900-luvun alkuvuosikymmeniltä peräisin olevat kuvat, joissa kansansoittajat on kuvattu eliitin konteksteissa kuten tutkijoiden työhuoneessa tai soittojuhlissa. Näitä kuvia harvemmin näkee, tutumpia ovat I. K. Inhan karjalaismaisemat ja kansallisromanttiset hämyisät pirtit. Kuvat tuovat konkreettisesti esille kanteleen kansallissoitin-symboliaseman taustalla olevan paradoksaalisen maiseman: erilaiset elämäntavat, yhteiskuntaluokat ja monin tavoin erillisistä maailmoista kotoisin olevat ihmiset kohtasivat toisensa eliitin omaksumassa 1800- ja 1900-luvun alun herderiläisessä aatemaailmassa.

Vaikuttavaa kanteleen historiassa on se, että se konkreettisesti soi läpi vuosisatojen ja -kymmenten eri yhteiskuntaluokissa huolimatta sen kansallissymbolisesta asemasta. Runolaulu kirjallistui monelta osin kansien väliin, mutta kantele pysyi käyttösoittimena. 1950- ja 1960-luvuilla siitä tuli jopa hienoinen muoti-ilmiö Martti ja Marjatta Pokelan suosion myötä. Pokela, edesmennyt Sibelius-Akatemian musiikkikasvatuksen opettaja, oli suosittu radio- ja tv-esiintyjä ja kansanmusiikin opetuksen pioneeri. Tenhunen esittelee Pokelan ja kanteleen vaiheita yksityiskohtaisesti ja liittää Pokelan merkittäväksi osaksi kanteleen kertomusta. Pokelan kautta versoi monia polkuja: kantelekursseja, -tapahtumia, -sävellyksiä, -oppimateriaaleja, jopa 1983 aloitettu kansanmusiikin koulutusohjelma Sibelius-Akatemiassa.

Tenhunen esittelee limittäin kantelepelimanneja ja 1900-luvun loppupuolen intomielistä etnomusikologian alan yliopistoväkeä, joka vaikutti kauaskantoisesti Suomessa muun muassa koulutuspoliittisiin päätöksiin, Kanteleliiton syntymiseen ja suomalaisen musiikkipedagogiikan linjauksiin. Jälkimmäiset Kantele-kirjassa nostetaan ehkäpä otsikossa mainitun "suuren nousun" taustajoukoksi, mutta pelimannien ääni on kirjassa kiitettävästi läsnä varsinkin Tenhusen osiossa.

Myös Tenhusen luvun loppupuolen kuvitus on kohdillaan: kotialbumeita on selvästi kaiveltu, ja kuvien arkipäiväistymisestä voi aistia käyttösoitinstatuksen asteittaisen paluun. Kansallisromanttinen symboliikka vilahtelee kuitenkin vielä vahvasti 1960-1990-lukujen kuvissa fereešeineen ja tanhukenkineen. 
Heidi Haapoja: Pysy Suomessa pyhänä

\section{SUOMALAINEN SOUNDI?}

Kuten kirjan viimeisen luvun nimestä "Kantelemusiikki” voi päätellä, paksu teos keskittyy alkupäässä lähinnä soittimen luonteeseen ja asemaan. Soiva musiikki huomioidaan tarkemmin vasta kirjan loppupuolella Pekka Jalkasen osiossa. Tämä on sinänsä hyvä ratkaisu, sillä Jalkasen musiikkitieteelliset analyysit vaativat melko syvällistä musiikinteoreettista tietämystä.

Jalkasenkin aikaperspektiivi ulottuu yli sadan vuoden taakse, mutta luvun pääpaino on 1960-luvun jälkeisissä vuosissa. Jalkanen on otsikoinut Martti Pokelan elämäntyötä luotaavan luvun sanalla "murros", mikä viittaa Jalkasen tekstissä Pokelan myötä syntyneeseen uuteen sävelmaailmaan. Pokela lisäsi soittoonsa uusia kromaattisia ja modaalisia virityksiä sekä uudenlaisia soittotapoja, mikä vaikutti huomattavasti kaikkeen myöhempään kantelemusiikkiin. Tämän mahdollistivat myös vivulliset, kromaattiset isot konserttikanteleet.

Uusi kantelemusiikki alkoi näin ollen eriytyä pelimannisoitosta, ja kantele alkoi saada uusia rooleja myös taide- ja populaarimusiikin saroilla. Jalkanen käy kiitettävän tarkasti läpi suomalaisen taidemusiikin kentällä tehtyjä kantelesävellyksiä, ja isossa roolissa ovat myös teoksista julkaistut nuottifragmentit. Nämä ovat musiikin kentällä toimiville mielenkiintoisia, mutta ehkä vaikeasti avautuvia muille. Kantelemusiikin erittely kaikenlaisten musiikkityylien kautta on silti kunniakas teko, sillä kantele useimmiten mielletään nimenomaan kansanmusiikin soittimeksi.

Kaiken kaikkiaan Kantele on taustatyön ja yksityiskohtien kannalta hyvin syväluotaava ja täsmällinen. Harvalla lienee tähän teokseen hetkeen kovinkaan paljon lisättävää, ainakaan faktojen puolesta. Mietityttämään jää vain kirjan yleinen diskurssi: omalta osaltaan kirja tuntuu toistavan kanteleen symboliasemaa pönkittävää kieltä siellä täällä purskahtavine romanttiskansallisine ja melko idealistisine lauselmineen ("Kanteleen ihme", "Suuri nousu" jne.). Välillä kirjoittajat taas tuntuvat tietoisesti pyrkivän tästä eroon korostamalla jonkinlaista musiikin universaaliutta ja kanteleen soinnin yleismaailmallista hienoutta. En tiedä, olisiko aihetta voinut lähestyä toisin, ehkä ei. Symboliasema vaatinee tiettyjen diskurssien läsnäoloa, ja monissa meissä vaikuttavat hyvin vahvasti aikaisempien vuosikymmenten ja jopa -satojen puhetavat.

Onneksi kanteleen roolia ei kirjassa ole esitetty pelkästään helisevän puhtoisena: tilaa on annettu myös varjoisille puolille, kuten kanteleen ja natsi-Saksan yhteyksille. Nationalismi on viimeiset vuosisadat ollut kanteleen päälle laskeutunut ideologinen verkko, ja tämä on Kanteleessa läsnä monella tavalla. Lieneekö vaade suomalaiskansallisuudesta se syy, että kanteletta ei ole kirjassa käsitelty kuin vain kursorisesti kansainvälisenä soittimena? Kanteleen kaltaisia soittimia tavataan Venäjän alueella ja Baltiassa useita, mutta näiden kytkösten esittely jää kirjassa hyvin lyhyeksi.

Teoksena kirja asettuu luontevasti suomalaisen jo yli sata vuotta tehdyn kansanmusiikin tutkimuksen jatkeeksi. Virkistävällä tavalla se tarttuu kuitenkin myös nykyisyyteen menneisyyden rinnalla, mikä on melko uutta kansanmusiikintutkimuksen vuossa. Myös kurottautuminen yli musiikkigenrerajojen on tuoretta ja varsin toimivaa. 
Heidi Haapoja: Pysy Suomessa pyhänä

\section{KirJallisuUs}

KUUSI, MATTI 1957: Kalevalaisen muinaisepiikan viisi tyylikautta. - Kalevalaseuran vuosikirja 37.

Filosofian maisteri, musiikin kandidaatti Heidi Haapoja tekee väitöskirjaa Helsingin yliopiston folkloristiikan oppiaineessa nykyrunolauluun liittyvästä puheesta. 